\title{
POTENSI SANTRI DALAM TRANSFORMASI DIGITAL LITERACY MEMASUKI ERA REVOLUSI INDUSTRI 4.0 DI PONDOK PESANTREN MODERN
}

\author{
Tulaihah Ning Safitri \\ Prodi Pendidikan Agama Islam, Fakultas Agama Islam, Universitas Nahdlatul Ulama \\ Indonesia \\ Email: tulaihah@unusia.ac.id
}

Article Information

InformasiArtikel

Naskah diterima : 25

Maret 2020

Naskah direvisi: 5 Mei 2020

Naskah disetujui : 3 September

Naskah dipublish: Oktober 2020

\begin{abstract}
This study aims to see the potential of students in digital literacy transformation entering the era of the industrial revolution 4.0 at the Modern Muhammadiyah Boarding School Sleman Islamic Boarding School, Yogyakarta. This study u sed descriptive qualitative method. Data were collected through observation and interviews with 10 students. The results of this study found that students have mastered the technology of 15 digital literacy transformation of students in the potential of mastering digital literacy. This is because Islamic boarding schools still limit the length of time they use technology. Although this pesantren has used modern pesantren. Pesantren leaders must balance religious education with technology so that graduates are not less competitive when they enter tertiary institutions and the world of work. For future researchers, it will be deeper in digging up information and using more samples.
\end{abstract}

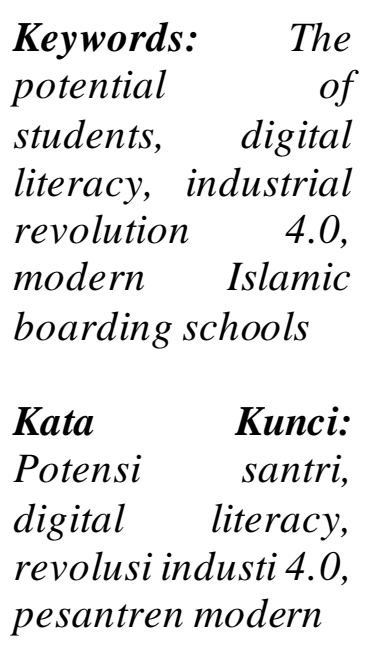

\section{Abstrak}

Penelitian ini bertujuan untuk melihat potensi santri dalam transformasi digital literacy memasuki era revolusi industri 4.0 di Pondok Pesantren Modern Muhammadiyah Boarding School Sleman Yogyakarta. Penelitian ini menggunakan metode deskriptif kualitatif. Data dikumpulkan melalui observasi dan wawancara dengan 10 santri. Hasil penelitian ini menemukan santri sudah menguasai teknologi tentang transformasi digital literacy santri dalam potensi penguasaan digital literacy. Karena Pondok pesantren masih membatasi durasi waktu dalam menggunakan teknologi. Meskipun pesantren ini sudah menggunakan pesantren modern. Kepada pimpinan pesantren harus menyeimbangkan antara pendidikan agama dengan teknologi agar lulusan tidak kalah saing ketika masuk ke perguruan tinggi maupun dunia kerja. Untuk peneliti selanjutnya, lebih mendalam dalam menggali informasi dan lebih banyak mengunaan sampel. 


\section{PENDAHULUAN}

Pendidikan merupakan suatu sistem yang harus dijalankan secara terpadu dengan sistem yang ada, guna mencapai tujuan yang telah ditetapkan. Selain itu untuk meningkatkan kualitas hidup manusia dalam segala aspek kehidupan. Pendidikan menjadi bagian paling primer dalam hidup manusia. Pernyataan tersebut diperkuat oleh (Dewantara, 2011) bahwa pendidikan itu merupakan penuntun segala kekuatan kodrat yang ada pada anak-anak, agar mereka sebagai manusia dan sebagai anggota masyarakat dapat mencapai keselamatan serta kebahagiaan yang setinggi-tingginya.

Mencerdaskan kehidupan bangsa bagian dari tujuan pendidikan nasional Indonesia. Pendidikan nasional berfungsi mengembangkan kemampuan dan membentuk watak serta peradaban bangsa yang bermartabat dalam rangka mencerdaskan kehidupan bangsa, bertujuan untuk berkembangnya potensi peserta didik agar menjadi manusia yang beriman dan bertakwa kepada Tuhan Yang Maha Esa, berakhlak mulia, sehat, berilmu, cakap, kreatif, mandiri, dan menjadi warga negara yang demokratis serta bertanggung jawab.

Pendidikan terbagi 2 yaitu pendidikan umum dan Pendidikan Islam. Pendidikan Islam pada dasarnya merupakan upaya pembinaan dan pengembangan potensi manusia, agar tujuan kehadirannya di dunia ini sebagai hamba Allah dan sekaligus tugas khalifah Allah tercapai sebaik mungkin. Potensi yang dimaksud meliputi potensi jasmaniah dan potensi rohaniah seperti akal, perasaan, kehendak, dan potensi rohani lainnya. Pendidikan Islam adalah upaya rencana dalam menyiapkan manusia untuk mengenal, memahami, menghayati, dan mempercayai ajaran agama Islam dengan dibarengi tuntutan untuk menghormati agama lain dalam hubungan antarumat beragama untuk menciptakan persatuan dan kesatuan bangsa (Mulyasa, 2005).

Konsep pendidikan didalam Islam menurut (Suwito, 2004) memandang bahwa manusia dilahirkan dengan membawa potensi lahiriah yaitu:1) potensi berbuat baik terhadap alam, 2) potensi berbuat kerusakan terhadap alam, 3) potensi ketuhanan yang memiliki fungsi-fungsi non fisik. Ketiga potensi tersebut kemudian diserahkan kembali perkembangannya kepada manusia. Pondok pesantren merupakan sebuah lembaga pendidikan dan keagamaan yang melakukan kegiatan sepanjang hari guna 
berusaha melestarikan, mengajarkan dan menyebarkan agama Islam serta melatih para santri untuk siap dan mampu mandiri (Subhan, 2012).

Kehidupan para santri tinggal di asrama dalam satu kawasan bersama guru, kyai, dan senior mereka. Oleh karena itu hubungan yang terjalin antara santri-gurukyai dalam proses pendidikan berjalan intensif, tidak sekedar hubungan formal ustadz-santri di dalam kelas melainkan dimanapun berada. Sedangkan Pondok modern (Mulkan, A. M., 1998) berusaha mewujudkan sistem pendidikan sinergik, yakni sistem yang memadukan akar tradisi dan modernitas. Jika strategi ini mampu dilaksanakan, hubungan pendidikan pondok pesantren dengan dunia kerja industrial dapat bersambung.

Perkembangan dunia sudah diwarnai global tecnology dimana seluruh kehidupan didunia ini mampu berkolaborasi kehidupan manusia dengan teknologi serba canggih dan modern. Apabila memasuki era revolusi industri 4.0. Segala sesuatu aspek urusan kehidupan manusia sudah tidak lepas dari teknologi. Mulai dari makan, minum, belanja, transportasi, transaksi dan lainnya sudah dikemas sedemikian rupa dengan teknologi. Teknologi menjadi kebutuhan primer manusia di era digital. Apabila tidak beradaptasi untuk mengikutinya, maka manusia dianggap gagap teknologi. Hal ini tidak dapat dihindari ataupun ditolak mengingat sudah menjadi sebuah kebutuhan pokok manusia. Oleh karena itu tuntutan kompetensi Digital Literacys kini menjadi tuntutan zaman yang menjanjikan dan paling dibutuhkan di era revolusi industri 4.0 pada saat sekarang ini.

Kemajuan teknologi dewasa ini sebenarnya memudahkan individu dalam memperoleh informasi lebih cepat dari sebelumnya seperti koran dan surat pos. Untuk menjalin hubungan komunikasi dengan beda tempat pasti akan mudah dan cepat, mengingat semuanya serba digital. Oleh karena itu globalisasi informasi dewasa ini tidak hanya diartikan sebagai arus komunikasi massa dalam arti sekedar penyebarluasan siaran televisi dan hiburan semata, namun sudah mencakup perluasan arus informasi ilmu pengetahuan dan teknologi yang mendorong perluasan cakrawala informasi dan wawasan pengetahuan manusia. Dalam arti yang lebih luas globalisasi ini merupakan suatu transformasi sosial budaya dengan ruang lingkup secara global (Yusuf, 2016). 
Kehadiran Digital Literacy (Literasi Digital) diharapkan dapat bermanfaat untuk pembangunan masyarakat terutama Digital Literacys sebagai tuntutan kompetensi yang sedang bersaing di pasar global. Karena di era revolusi indu stri 4.0 tidak hanya orang dewasa yang dituntut untuk bekerja melainkan semua kalangan dapat bekerja dengan bantuan teknologi. Salah satu contohnya adalah menjadi content creator, youtuber, vlogger, desainer logo dan masih banyak yang dapat diak ses oleh semua kalangan sehingga Digital Literacy sangat dibutuhkan dan sangat berperan penting di era revolusi industry 4.0 .

Manusia menggunakan teknologi karena memiliki akal. Dengan akalnya manusia ingin keluar dari masalah, ingin hidup lebih baik, dan lebih aman. Perkembangan teknologi terjadi karena seseorang menggunakan akalnya untuk menyelesaikan setiap masalah yang dihadapinya. Kemajuan teknologi adalah sesuatu yang tidak dapat dihindari dalam kehidupan ini, karena kemajuan teknologi akan berjalan sesuai dengan kemajuan ilmu pengetahuan. Setiap inovasi diciptakan untuk memberikan manfaat positif bagi kehidupan manusia.

Teknologi memberikan banyak kemudahan, serta sebagai cara baru dalam melakukan aktivitas manusia. Manusia sudah menikmati banyak manfaat yang dibawa oleh inovasi-inovasi teknologi yang telah dihasilkan dalam dekade terakhir ini. Pada era globalisasi saat ini, penguasaan teknologi menjadi prestise dan indikator kemajuan suatu negara. Negara dikatakan maju jika memiliki tingkat penguasaan teknologi tinggi (high technology), sedangkan negara-negara yang tidak dapat beradaptasi dengan kemajuan teknologi sering disebut sebagai negara gagal (failed country). Namun apakah teknologi ini berdampak kepada kehidupan para santri di lembaga pendidikan islam seperti pesantren?.

Kemajuan teknologi informasi dan internet saat ini mengakibatkan sumber daya informasi digital sangat melimpah (Kurnianingsih \& Ismayati, 2017). Perkembangan teknologi informasi diibaratkan seperti dua sisi mata uang yang memberikan efek positif dan negatif kepada masyarakat. Pembelajaran literasi digital tidak dapat dihindari (Anggraeni, H. Fauziyah, Y dan Fahyuni, E., 2019; Setyaningsih $\&$ Prihantoro, 2012). Tuntutan inilah yang kemudian melahirkan sebuah pemikiran tentang pentingnya literasi digital, termasuk dalam dunia pendidikan. Berikut gambar kebutuhan teknologi: 


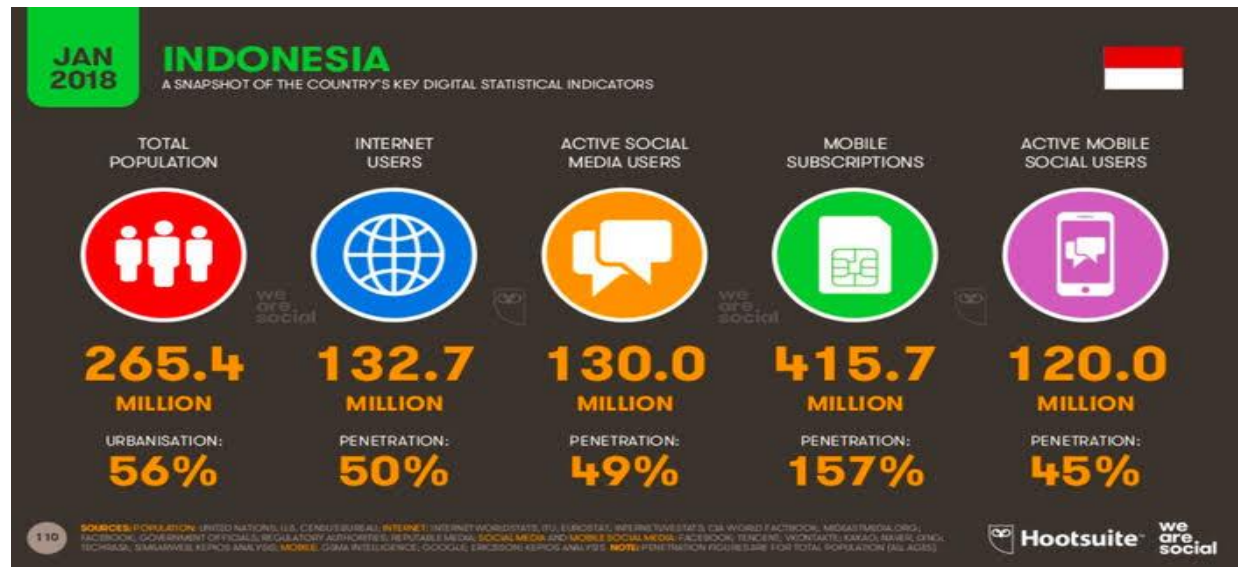

Gambar 1. Grafik Presentase Kebutuhan Teknologi Tahun 2018 (Sumber: APJII)

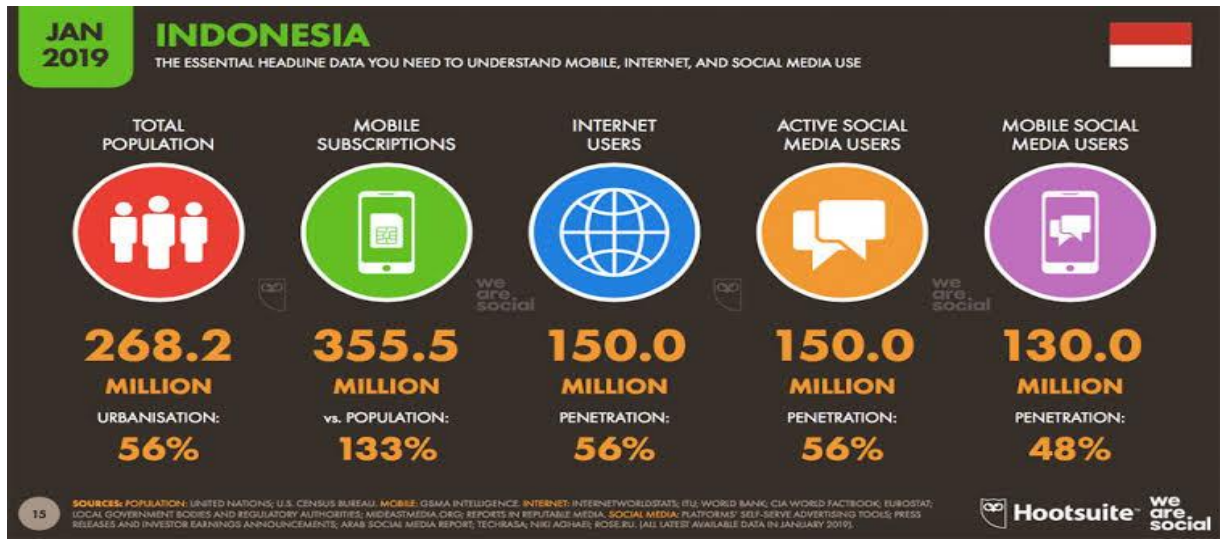

Gambar 2. Grafik Presentase Kebutuhan Teknologi Tahun 2019 (Sumber: APJII)

Tabel 1. Daftar Pengguna Internet Terbanyak Di Dunia Tahun 2019

\begin{tabular}{|l|l|r|r|r|r|r|}
\hline \multicolumn{7}{|c|}{ TOP 20 COUNTRIES WITH HIGHEST NUMBER OF } \\
INTERNET USERS - MARCH 31, 2019 \\
\hline \# & Country or Region & $\begin{array}{c}\text { Population, } \\
2019 \text { Est. }\end{array}$ & $\begin{array}{c}\text { Population } \\
2000 \text { Est. }\end{array}$ & $\begin{array}{c}\text { Internet Users } \\
31 \text { Mar 2019 }\end{array}$ & $\begin{array}{c}\text { Internet Users } \\
31 \text { Dec 2000 }\end{array}$ & $\begin{array}{c}\text { Internet Growth } \\
2000.2019\end{array}$ \\
\hline 1 & China & $1,420,062,022$ & $1,283,198,970$ & $829,000,000$ & $22,500,000$ & $3,584 \%$ \\
\hline 2 & India & $1,368,737,513$ & $1,053,050,912$ & $560,000,000$ & $5,000,000$ & $11,100 \%$ \\
\hline 3 & United States & $329,093,110$ & $281,982,778$ & $292,892,868$ & $95,354,000$ & $207 \%$ \\
\hline 4 & Brazil & $212,392,717$ & $175,287,587$ & $149,057,635$ & $5,000,000$ & $2,881 \%$ \\
\hline 5 & Indonesia & $269,536,482$ & $211,540,429$ & $143,260,000$ & $2,000,000$ & $7,063 \%$ \\
\hline 6 & Japan & $126,854,745$ & $127,533,934$ & $118,626,672$ & $47,080,000$ & $152 \%$ \\
\hline 7 & Nigeria & $200,962,417$ & $122,352,009$ & $111,632,516$ & 200,000 & $55,716 \%$ \\
\hline 8 & Russia & $143,964,709$ & $146,396,514$ & $109,552,842$ & $3,100,000$ & $3,434 \%$ \\
\hline 9 & Bangladesh & $168,065,920$ & $131,581,243$ & $92,061,000$ & 100,000 & $91,961 \%$ \\
\hline 10 & Mexico & $132,328,035$ & $101,719,673$ & $85,000,000$ & $2,712,400$ & $3,033 \%$ \\
\hline
\end{tabular}


Berdasarkan gambar 1 di atas, bahwa pengguna internet di Indonesia sangat banyak mencapai 132,7 juta jiwa dalam presenstase $50 \%$ dari jumlah populasi penduduk di Indonesia pada tahun 2018. Kemudian selanjutnya pada gambar 2. Ternyata ada angka penambahan yang sangat signifikan pada jumlah pengguna jasa internet hingga mencapai 355,5 juta jiwa dalam presentase $133 \%$ di Indone sia p ada tahun 2019 (Sumber: APJII). Selanjutnya pada tabel 3, bahwa negara Indonesia menduduki peringkat ke 5 sebagai pengguna jasa internet terbesar di dunia. Angka ini memiliki makna tersirat yang menunjukkan bahwa tranformasi Digital Literacy $s$ (Literasi Digital) di Indonesia begitu didukung sehingga perlunya pemanfaatan yang tepat sasaran kepada wirausaha start up, pendidikan sistem online dengan menyesuaikan kebutuhan revolusi industri 4.0. kemudian memanfaatkan social media atau aplikasi yang mampu bermanfaat bagi orang banyak.

Konsep digitalisasi yang sedang terjadi diberbagai sektor kehidupan dalam memasuki revolusi industri 4.0, membuat dilemanya para santri lulusan pesantren yang berlatar belakang paham agama, ahli bahasa dan penghafal Qur'an terhadap jaminan masa depan. Keadaan ini yang mengkhawatirkan melahirkan lulusan yang gagap teknologi, tentu Potensi yang ingin diraup adalah bagaimana para santri mampu menyerap konsep Digital Literacys melalui tranformasi dari pendidikan tradisional.

\section{METODOLOGI PENELITIAN}

Penelitian ini menggunakan metode deskriptif kualitatif untuk menemukan potensi santri dalam transformasi digital literacy memasuki era revolusi industri 4.0 yang dilakukan di Pondok Pesantren Modern Muhammadiyah Boarding School Sleman Yogyakarta. Data dalam penelitian ini diperoleh melalui observasi secara langsung serta wawancara mendalam. Observasi dilakukan dengan melakukan pengamatan secara langsung kegiatan santri. Wawancara dilakukan dengan santri yang terdiri dari 10 orang. Wawancara dilakukakan secara mendalam tentang transformasi digital literacy santri yang terdiri dari potensi penguasaan digital literacy. Setelah melakukan observasi dan wawancara mendalam, peneliti mengonstruksi pesan-pesan yang diperoleh dari informan dan memetakan pemanfaatan potensi penguasaan digital literacy untuk. Teknik analisis data dilakukan berdasarkan teori Miles dan Huberman, ada tiga proses tahapan dalam analisa data (1) reduksi data, (2) display data, dan (3) konklusi data menurut interpretasi peneliti 
(Tamin, 2011). Reduksi dilakukan dengan cara merangkum, memilih hal-hal yang pokok, dan memfokuskan pada hal-hal yang penting. Penyajian data dalam bentuk uraian singkat, bagan, hubungan antar kategori, flowchart dan sejenisnya. Penarikan kesimpulan/ verifikasi merupakan alur ketiga dalam teknik analisis data setelah reduksi dan penyajian data. Keabsahan data penelitian dilakukan dengan triangulasi. Triangulasi adalah suatu cara mendapatkan data yang benarbenar absah dengan menggunakan metode ganda (Bachri, 2010). Teknik pengumpulan data yang bersif at menggabungkan dari berbagai teknik dan sumber data yang ada. Triangulasi data dalam penelitian ini adalah triangulasi metode yang dilakukan dengan cara menggabungkan teknik observasi dan wawancara, dan menggabungkan sumber data dari beberapa subjek penelitian

\section{KAJIAN TEORI}

\section{Potensi}

Kata potensi berasal dari bahasa Inggris “to patent” yang berarti keras, kuat. Dalam pemahaman lain, kata potensi mengandung arti kekuatan, kemampuan, daya, baik yang belum maupun yang sudah terwujud, tetapi belum optimal. Sementara menurut Kamus Umum Bahasa Indonesia, yang dimaksud potensi adalah kemampuan dan kualitas yang dimiliki oleh seseorang, namun belum dipergunakan secara maksimal. Berbagai pengertian di atas, memberi pemahaman kepada kita bahwa potensi merupakan suatu daya yang dimiliki oleh manusia, tetapi daya tersebut belum dimanfaatkan secara optimal. Oleh karena itu, tugas berikutnya bagi manusia yang berpotensi adalah bagaimana mendayagunakan potensi tersebut untuk meraih prestasi.

Potensi dapat menjadi perilaku apabila dikembangkan melalui proses pembelajaran. Orang tidak dapat mewujudkan potensi diri dalam perilaku apabila potensi yang dimiliki itu tidak dikembangkan melalui pembelajaran. Potensi yang dimiliki oleh manusia dapat berkembang kearah yang baik atau tidak baik. Jika seseorang hidup di lingkungan yang tidak baik, potensinya akan berkembang kearah yang tidak baik sehingga perilakunya tidak baik. Untuk mencegah perilaku yang tidak baik, manusia memerlukan usaha yang sadar dan sistematis untuk menangkalnya. Usaha tersebut diperoleh melalui pendidikan secara formal maupun nonformal, disamping pendidikan pergaulan yang baik. 


\section{Pesantren}

\section{a) Pengertian pesantren}

Perkataan pesantren berasal dari kata santri yang diberi awalan pe di depan dan akhiran an berarti tempat tinggal para santri (Maunah, 2009). Pesantren di Indonesia tidak hanya sebagai tempat tinggal santri, namun pesantren adalah tempat dimana para santri menuntut ilmu. Hal ini menunjukkan bahwa pesantren bagaikan rumah kedua bagi santri. Terminologi pesantren di atas, mengidentifikasi bahwa secara kultural pesantren lahir dari budaya Indonesia.

Pondok pesantren (Al-Husaini, 2010) merupakan kata majemuk y ang terdiri dari kata Pondok dan Pesantren. Pondok berasal dari kata funduk (bahasa Arab) yang berarti tempat singgah. Sedangkan pesantren adalah lembaga pendidikan Islam y ang dalam pembelajarannya tidak dalam bentuk klasikal. Jadi, pondok pesantren berarti lembaga pendidikan Islam nonklasikal dimana peserta didik (santri atau murid) disediakan tempat singgah atau pemondokan. Menurut (Nurcholis, 1997) pondok pesantren adalah tempat berkumpulnya para santri atau asrama tempat mengaji ilmu agama Islam, di mana santri mempunyai gambaran sebagai seorang yang mengerti lebih jauh mengenai perihal agama dibandingkan dengan masyarakat umum.

Sebagai wadah lembaga pendidikan Islam, pendidikan di pesantren ditujukan untuk menanamkan keimanan dan ketakwaan kepada Allah SWT, akhlak mulia, serta tradisi pesantren untuk mengembangkan kemampuan, pengetahuan, dan life skill peserta didik untuk menjadi ahli ilmu agama Islam dan menjadi muslim yang memiliki life skill untuk membangun kehidupan yang islami di masyarakat.

Berdasarkan sistem dan media pembelajarannya, pesantren dapat dibedakan menjadi dua kelompok (tipologi), yaitu pesantren tradisional (salaf) dan pesantren modern (khalaf). Keduanya merupakan wajah pesantren yang tampil baru -baru ini. Untuk tipologi pesantren modern sendiri masih tergolong baru, karena muncul di Indonesia pada awal abad ke 20. Kategori pondok pesantren tradisional dan pondok pesantren modern dilihat berdasarkan beberapa aspek, yaitu kepemimpinan, institusi, kurikulum, metode pendidikan, dan fasilitas yang disediakan di pondok pesantren.

1) Pesantren Tradisional Pesantren tradisional atau salaf

Pondok pesantren yamg tetap mempertahankan pelajaran dengan kitab-kitab klasik dan tanpa diberitahukan pengetahuan umum. Kepemimpinan pondok pesantren 
tradisional atau salaf menggunakan kepemimpinan individual kyai. Kyai memiliki dua peranan yakni sebagai pengasuh sekaligus pemilik pondok pesantren. Kyai merupakan figur sentral di dunia pendidikan pesantren dan lebih dari itu merupakan faktor determinan terhadap suksesnya santri dalam mencari pengetahuan. (Abdurahman Wahid, 1984:20).

Pondok pesantren tradisional biasanya menggunakan langgar, surau atau masjid digunakan sebagai kebutuhan dasar dari institusi mereka. Sebuah mushola atau masjid bukan hanya untuk kegiatan ibadah melainkan sebagai tempat pusat pendidikan. Pad a perkembangan selanjutnya, ketika jumlah santri yang sudah semakin banyak dan masjid tidak mampu menampung jumlah santri, maka para kyai membangun penginapan santri atau biasa yang disebut dengan asrama (Wahid, 1999).

Kurikulum dan Metode Pembelajaran Pesantren Kurikulum pondok pesantren tradisional mengunakan kurikulum yang masih sederhana, yaitu hanya berisi inti ajaran Islam, iman dan ihsan. Lebih dari itu, kyai sudah menaruh perhatian untuk bagaimana kemudian doktrin, ritual dan ajaran mistikus Islam dapat terus dikembangkan dalam pondok pesantren. Penyampaian komponen Iman, Islam dan dan Ihsan merupakan tiga komponen yang paling mendasar, sebab disesuaikan dengan tingkat intelektual dengan santri,

2) Pesantren Modern

Seiring dinamika zaman, banyak pesantren yang mengunakan sistem pendidikannya yang pada awalnya adalah salaf, lalu diubah menjadi pesantren modern. Ciri khas pesantren modern adalah memprioritaskan pendidikan pada sistem sekolah formal dan lebih menekankan pada bahasa arab modern (lebih spesifik pada speaking atau muhawarah. Kepemimpinan pondok pesantren modern tidak menggunakan sistem kepemimpinan seorang kyai karena bersinggungan dengan yayasan. Dengan hal ini beban kyai jadi lebih ringan karena ditangani bersama sesuai dengan tugas masing-masing. Kyai tidak terlalu menanggung beban moral tentang kelanjutan pondok pesantren tersebut.

Bentuk institusi yang digunakan dalam pondok pesantren modern menurut (Karel, 1984) adalah madrasah. Jika sebelum abad ke 20, tradisi pondok pesantren belum mengenal istilah madrasah, kecuali pengajian Al-Quran, masjid, pondok pesantren, surau, langgar dan tajug.38 Kehadiran madrasah sebagai salah satu institusi 
pondok pesantren memiliki konsekuensi yang signifikan karena sistem pendidikan modern berbeda dengan pondok pesantren tradisional.

Kurikulum dan Metode Pembelajaran Pesantren modern mengkombinasikan antara pesantren salafi dan model pendidikan formal dengan mendirikan satuan pendidikan semacam SD/MI, SMP/MTS, SMA/SMK/MA, bahkan sampai pada perguruan tinggi. Kurikulum yang digunakan adalah kurikulum pesantren salaf yang diadaptasikan dengan pendidikan kurikulum pendidikan Islam yang disponsori oleh Departemen Agama dalam sekolah (madrasah). Maka orientasi keilmuan di pondok pesantren tetap berpusat pada ilmu-ilmu agama. Sementara ilmu-ilmu umum dipandang sebagai suatu kebutuhan. Pondok pesantren modern menerapkan sistem perpaduan dengan pondok pesantren tradisional (salaf).

Oleh karena itu Pembelajaran di pondok pesantren tidak sepenuhnya menggunakan pendekatan partisipatif terutama dalam perencanaan pembelajaran, karena tidak semua proses pembelajaran tersebut harus melibatkan santri. Akan tetapi, bagi santri yang telah dewasa (santri salafiyah) karena mereka mempunyai pengalaman, mempunyai konsep diri, kesiapan untuk belajar, orientasi terhadap belajar sehingga dilibatkan dalam perencanaan pembelajaran.

\section{PESANTREN SEBAGAI PUSAT PENDIDIKAN ISLAM}

Didalam dunia pendidikan Islam, bahwa ada dua makna yang membahas mengenai terminologi Pendidikan Islam. Pertama, pendidikan tentang Islam, kedua pendidikan menurut Islam. Terminologi pertama lebih memandang Islam sebagai subjec matter dalam pendidikan, sedangkan terminologi kedua lebih menempatkan Islam sebagai perspektif dalam Pendidikan Islam.

Muhammad Hamid An-Nashir dan Qullah Abdul Qadir Darwis mendefinisikan pendidikan Islam sebagai proses pengarahan perkembangan manu sia pada sisi jasmani, akal, bahasa, tingkah laku, dan kehidupan sosial keagamaan y ang diarahkan pada kebaikan menuju kesempurnaan. Sementara itu Omar Muhammad AtTaumi Asy-Syaibani sebagaimana dikutip oleh (Arifin, 1987), menyatakan bahwa pendidikan Islam adalah usaha mengubah tingkah laku individu dalam kehidupan pribadi atau kehidupan kemasyarakatan dan kehidupan di alam sekitarnya. Jika pendidikan Islam difahami dengan pengertian yang pertama, maka proses yang terjadi adalah pengalihan nilai-ilai Islam (Transfer of Islamic values) dari generasi tua 
kepada generasi muda tanpa harus menciptakan kondisi yang membuat anak didik berfikir kreatif dan progresif.

Oleh karena itu, tujuan pendidikan pada hakekatnya harus berupaya menciptakan suasana belajar dan proses pembelajaran yang dapat memberikan bekal bagi peserta didik dengan berbagai kecakapan hidup (life skills). Pendidikan tidak hanya mengejar pengetahuan semata tetapi harus ada proses pengembangan keterampilan, sikap, dan nilai-nilai tertentu yang dapat direfleksikan dalam kehidupan peserta didik dimasa yang akan datang.

\section{DIGITAL LITERACY}

Perkembangan teknologi informasi menjadi bagian dari munculnya era revolusi digital di Indonesia. Perkembangannya yang sangat pesat mampu memberikan pengaruh besar dan mendominasi seluruh sektor kehidupan masyarakat, termasuk di dunia pendidikan. Tuntutan akademik pada tiap jenjang pendidikan di Indonesia berbeda-beda (Akbar \& Anggaraeni, 2017). Digital-age dalam dunia pendidikan, khususnya pada pendidikan tinggi, memiliki konsekuensi berupa desain pembelajaran dengan memanfaatkan media digital sebagai sarana untuk meningkatkan pengetahuan mahasiswa. Media digital dapat menyajikan materi pembelajaran secara kontekstual, audio maupun visual secara menarik dan interaktif (Umam, Kaiful; Zaini: 2013).

Berbicara Digital Literacy berarti berbicara konsep kecakapan hidup (life skills). Dimana konsep ini telah lama menjadi perhatian para ahli dalam pengembangan kurikulum, Tyler (1947) dan Taba (1962) misalnya, men gemukakan bahwa kecakapan hidup merupakan salah satu fokus analisis dalam pengembangan kurikulum pendidikan yang menekankan pada kecakapan hidup dan bekerja. Pengembangan kecakapan hidup itu mengedepankan aspek-aspek berikut:

1) Kemampuan yang relevan untuk dikuasai peserta didik.

2) Materi pembelajaran sesuai dengan tingkat perkembangan peserta didik.

3) Kegiatan pembelajaran dan kegiatan peserta didik untuk mencapai kompetensi.

4) Fasilitas, alat dan sumber belajar yang memadai, dan

5) Kemampuan-kemampuan yang dapat diterapkan dalam kehidupan peserta didik. 
Kecakapan hidup (life skills) pada dasarnya adalah kemampuan seseorang untuk berjuang berani hidup (survival). Untuk itu pengembangan kecakapan hidup (life skills) pada seseorang perlu proses pendidikan dan latihan yang pada dasarnya bertujuan untuk memperoleh kemampuan dasar. Karena tanpa bekal kemampuan dasar, seseorang akan sulit untuk mengembangkan kecakapan hidupnya (Satori : 2002).

Dari beberapa definisi diatas, maka dapat diambil kesimpulan bahwa dalam literasi digital itu bukan hanya sekedar kemampuan mencari, menggunakan dan menyebarkan informasi. Akan tetapi, diperlukan kemampuan dalam membuat informasi dan evaluasi kritis, ketepatan aplikasi yang digunakan dan pemahaman mendalam dari isi informasi yang terkandung dalam konten digital tersebut. Disisi lain literasi digital mencakup tanggung jawab dari setiap penyebaran informasi yang dilakukannya karena menyangkut dampaknya terhadap masyarakat.

\section{a) Manfaat Literasi Digital}

Menurut Brian Wright (2015) dalam infographics yang berjudul “Top 10 Benefits of Digital Literacy: Why You Should Care About Technology", bahwa ada 10 manfaat penting dari adanya literasi digital yaitu: 1). Belajar lebih cepat, 2). Menghemat uang, 3). Membuat lebih aman, 4). Selalu memperoleh informasi terkini, 5). Selalu terhubung, 6). Membuat keputusan yang lebih baik, 7). Dapat membuat anda bekerja, 8). Membuat lebih bahagia, 9). Mempengaruhi dunia, 10). Men ghe mat waktu.

Digital Literacy adalah bagian dari keterampilan abad 21 yaitu keterampilan belajar dan inovasi, berpikir kritis dalam pemecahan masalah, komunikasi dan keterampilan kolaborasi. Menurut Alkalai (2004) terdapat 5 jenis kemahiran yang termasuk dalam digital literacy meliputi:

1) Photo-visual literacy adalah kemampuan untuk membaca dan menyimpulkan informasi dari visual;

2) Reprodusi literacy adalah kemampuan untuk menggunakan teknologi digital untuk menciptakan karya baru dari pekerjaan;

3) Percabangan literacy adalah kemampuan untuk berhasil menavigasi di media nonlinear dari ruang digital; 
4) Informasi literacy adalah kemampuan untuk mencari, menemukan, menilai dan mengevaluasi secara kritis informasi yang ditemukan di web;

5) Sosio-emosional literacy mengacu pada aspek-aspek sosial dan emosional hadir secara online, apakah itu mungkin melalui sosialisasi, dan berkolaborasi atau hanya mengkonsumsi konten.

\section{b) Elemen Literasi Digital}

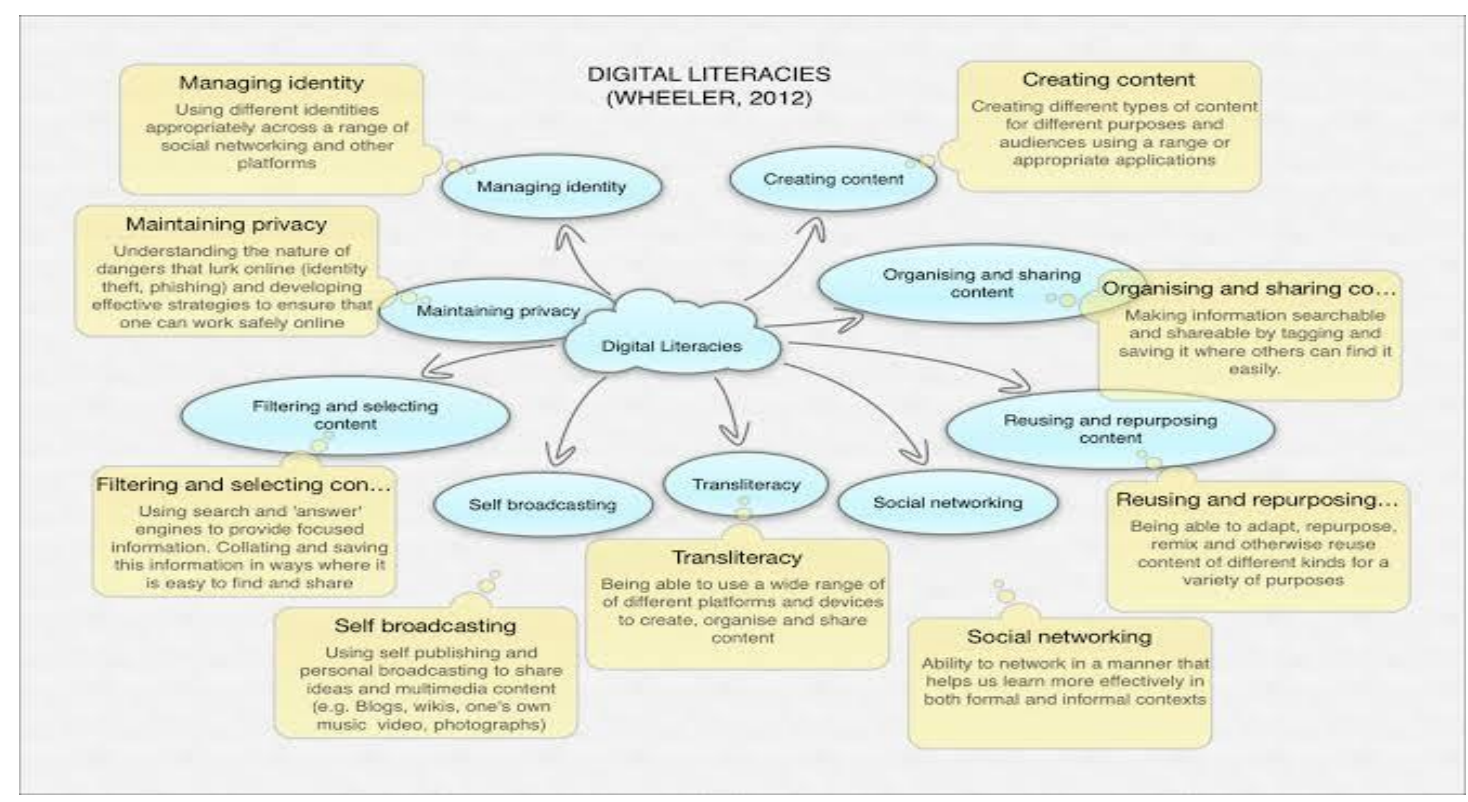

Gambar 3. The Seven Element Digital Literacy (Wheeler, 2013)

Adapun Tujuh elemen literasi digital sesuai dengan kebutuhan revolusi industri 4.0 meliputi:

1) Information literacy adalah kemampuan mencari, mengevaluasi dan menggunakan informasi yang dibutuhkan secara efektif (Hasugian, 2008),

2) Digital scholarship adalah elemen yang mencakup partisipasi aktif pengguna media digital dalam kegiatan akademik untuk menjadikan informasi dari media digital tersebut sebagai referensi data, misalnya pada praktik penelitian atau penyelesaian tugas kuliah (Stefany, S. Nurbani, 2017).

3) Learning skills merupakan belajar secara efektif berbagai teknologi yang mempunya fitur-fitur lengkap untuk aktivitas pembelajaran formal maupun informal. 
4) ICT literacy atau disebut dengan melek teknologi informasi dan komunikasi yang fokus pada cara-cara untuk mengadopsi, menyesuaikan dan menggunakan perangkat digital dan media berbasis TIK baik aplikasi dan layananya. Media berbasis TIK yang dimaksud misalnya komputer atau LCD proyektor/power point yang telah didesain atau dirancang sedemikian rupa agar dapat dimanfaatkan sesuai dengan pemahamannya, apalagi sudah terkoneksi dengan internet sebagai basis pembelajarannya (Budhirianto, 2016).

5) Career and identy management berkaitan dengan cara-cara mengelola identitas online. Identitas seseorang dapat diwakili oleh sejumlah avatar berbeda yang mampu melakukan hubungan dengan lebih dari satu pihak dalam waktu yang hampir bersamaan (Damayanti, Maria Nala; Yuwono:2013).

6) Communication and collaboration merupakan bentuk partisipasi secara aktif untuk pembelajaran dan penelitian melalui jaringan digital, dan

\section{REVOLUSI INDUSTRI}

Era Revolusi Industri 4.0 membawa dampak yang tidak sederhana. Ia berdampak pada seluruh aspek kehidupan manusia. Termasuk dalam hal ini adalah pendidikan. Era ini ditandai dengan semakin sentralnya peran teknologi cyber dalam kehidupan manusia. Maka tak heran jika dalam dunia pendidikan muncul istilah "Pendidikan 4.0". Pendidikan 4.0 (Education 4.0) adalah istilah umum digunakan oleh para ahli pendidikan untuk menggambarkan berbagai cara untuk mngintegrasikan teknologi cyber baik secara fisik maupun tidak ke dalam pembelajaran. Ini adalah lompatan dari pendidikan 3.0 yang menurut Jeff Borden mencakup pertemuan ilmu saraf, psikologi kognitif, dan teknologi pendidikan. Pendidikan 4.0 adalah fenomena yang merespon kebutuhan munculnya revolusi industri keempat dimana manusia dan mesin saling berkolaborasi untuk mendapatkan solusi, memecahkan masalah dan tentu menemukan inovasi baru.

Sejarah revolusi industri dimulai dari industri 1.0, 2.0, 3.0, hingga industri 4.0.Revolusi Industri 4.0 sebagai fase revolusi teknologi mengubah cara beraktifitas manusia dalam skala, ruang lingkup, kompleksitas, dan transformasi dari pengalaman hidup sebelumnya. Manusia bahkan akan hidup dalam ketidakpastian (uncertainty) global, oleh karena itu manusia harus memiliki kemampuan untuk memprediksi mas a depan yang berubah sangat cepat. Menghadapi revolusi industri 4.0 tentu bukan hal 
mudah, sehingga mempersiapkan hal-hal yang terkait dengan hal tersebut menjadi suatu keharusan.

Salah satu elemen penting yang harus menjadi perhatian untuk mendorong pertumbuhan ekonomi dan daya saing bangsa di era revolusi industri 4.0 adalah mempersiapkan sistem pembelajaran yang lebih inovatif, dan meningkatkan kompetensi lulusan yang memiliki keterampilan abad ke-21 (Learning and Innovations Skills). Oleh karena trend di abad 21 lebih berfokus pada spesialisasi tertentu, maka tujuan pendidikan nasional Indonesia harus diarahkan pada upaya membentuk keterampilan dan sikap individu abad 21. Lima domain utama keterampilan abad 21 adalah literasi digital, pemikiran yang intensif, komunikasi efektif, produktifitas tinggi dan nilai spiritual serta moral (Osman, Hiong, Vebrianto, \& Omar, 2020).

\section{DAMPAK REVOLUSI INDUSTRI 4.0}

Revolusi Industri sebagai salah satu revolusi penting dunia juga memiliki pengaruh yang sangat kuat terhadap Indonesia. Secara garis besar Revolu si Industri memiliki pengaruh yang positif dan negatif. Antara keduanya saling berhubungan satu sama lainnya. Berikut ini adalah dampak Revolusi Industri terhad ap perkembangan sejarah Indonesia. Dampak adanya Revolusi Industri di Inggris

1) Inggris menjadi negara industri

2) Terjadi urbanisasi

3) Munculnya lapisan sosial baru: golongan buruh dan borjui

4) Munculnya konflik sosial

5) Timbulnya kapitalisme modern, yaitu susunan ekonomi yang berpusat pada keberuntungan perseorangan dimana uang memegang peranan penting. Bidang Ekonomi

6) Barang melimpah dan harga murah

7) Perusahaan Kecil Gulung Tikar

8) Perdagangan makin berkembang

9) Transportasi makin lancar Bidang Sosial

10) Berkembangnya Urbanisasi

11) Upah buruh rendah

12) Munculnya golongan pengusaha dan golongan buruh

13) Adanya kesenjangan antara majikan dan buruh

14) Munculnya Revolusi Sosial 


\section{TANTANGAN KE DEPAN PENDIDIKAN PONDOK PESANTREN}

The World Economic Forum (WEF) menyatakan bahwa revolusi ind u stri 4.0 ditandai oleh pembauran (fusion) teknologi yang mampu menghapus batas-batas penggerak aktivitas ekonomi, baik dari perspektif fisik, digital, maupun biologi. Dengan bahasa yang lebih sederhana dapat dikatakan bahwa pembauran teknologi mampu mengintegrasikan faktor sumber daya manusia, instrumen produksi, serta metode operasional, dalam mencapai tujuan.

Karakteristik revolusi industri 4.0 ditandai dengan berbagai teknologi terapan (applied technology), seperti advanced robotics, artificial intelligence, internet of things, virtualand augmented reality, additive manufacturing, serta distributed manufacturing yang secara keseluruhan mampu mengubah pola produksi dan model bisnis di berbagai sektor industri. Adapun pengertian dari istilah-istilah tersebut adalah:

1) Advanced Robotics. Instrumen ini merupakan peralatan yang digunakan secara mandiri, yang mampu berinteraksi secara langsung dengan manusia, serta menyesuaikan perilaku berdasarkan sensor data yang diberikan. Fungsi utamanya adalah untuk memperpendek waktu tunggu dan waktu layanan, sehingga menghasilkan efisiensi.

2) Artificial Intelligence (AI). AI adalah sistem mesin berteknologi komputer yang mampu mengadopsi kemampuan manusia. Ini dimaksudkan untuk meningkatkan kinerja dan produktivitas, sekaligus meminimalisir risiko kesalahan yang dapat dilakukan oleh tenaga kerja manusia.

3) Internet of Things (IoT). IoT merupakan teknologi yang memungkinan setiap instrumen terkoneksi satu sama lain secara virtual, sehingga mampu mendukung kinerja operasioanal usaha, pengawasan terhadap perfoma manajemen, serta peningkatan nilai guna output.

4) Virtual and Augmented Reality. Virtual Reality merupakan simulasi yang dilakukan oleh komputer dalam membentuk sebuah realitas rekaan. Teknologi ini mampu memanipulasi penglihatan manusia sehingga seolah-olah berada di tempat atau lingkungan yang berbeda dari kenyataan sesungguhny a. Sementara Augmented Reality adalah teknologi yang mampu menghasilkan informasi dari 
kondisi lingkungan sebenarnya, lalu diproses secara digital dan digunakan untuk tujuan tertentu.

5) Additive Manufacturing. Teknologi ini merupakan otomatisasi proses produksi melalui teknologi 3D (three dimensional). Hal ini memberi pengaruh positif pada kecepatan pengolahan dan transportasi produk.

6) Distributed Manufacturing. Merupakan konsep penempatan lokasi produksi dan pengintegrasian proses produksi, sehingga dapat berada sedekat mungkin dengan konsumen untuk menjawab kebutuhan riil mereka. Tujuannya adalah untuk mencapai economies ofscale, sekaligus mengurangi beban biaya (cost efficiency).

Melalui penerapan teknologi modern, sektor industri tidak lagi semata-mata berfokus pada pengembangan usaha dan peningkatan laba, melainkan pada pendayagunaan dan optimalisasi setiap aktivitas, mulai dari pengadaan modal, proses produksi, hingga layanan kepada konsumen (World economic Forum). Impact of the Fourth Industrial Revolution on Supply Chains, October: 2017). Selain membawa dampak positif, revolusi industri 4.0 memunculkan berbagai tantangan yang mesti dijawab.

The United Nations Industrial Development Organization (UNIDO) menekankan agar kehadiran industri 4.0 dapat meningkatkan perekonomian negaranegara miskin dan berkembang, sekaligus mendorong terwujudnya agenda-agenda pembangunan seperti yang tertuang dalam the Sustainable Development Goals (SDGs). Namun demikian UNIDO juga mengkhawatirkan terjadinya gap yang semakin besar diantara negara-negara maju yang mampu mengaplikasikan teknologi modern, dengan negaranegara miskin dan berkembang yang tertinggal dalam pengembangan teknologi.

Masalah yang tidak kalah penting adalah dampak penerapan teknologi terhadap peran tenaga kerja serta pemeratan kesejahteraan. UNIDO menegaskan beberapa poin penting terkait perkembangan industri 4.0, yakni:

1) Industri 4.0 diharapkan memberi manfaat untuk kepentingan manusia, lingkungan, dan kesejahteraan bersama.

2) Industri 4.0 diharapkan mampu mendorong pengembangan kapasitas manusia, sehingga menjadi semakin terdidik dan terampil. 
3) Akses terhadap teknologi diharapkan terjangkau dengan mudah, sehingga dapat diterapkan di semua negara.

4) Kemajuan teknologi diharapkan mampu menghasilkan keterbukaan informasi.

5) Kemajuan teknologi diharapkan dapat menggeser paradigma lama, dari persaingan (competition) menjadi koneksi (connection) dan kerjasama (collaboration).

6) Penerapan teknologi diharapkan mampu menjawab tantangan perubahan iklim dan upaya pelestarian lingkungan.

(UNIDO. Industry 4.0: Opportunitiesand Challenges of the New Industrial Revolution for Developing Countriesand Economies in Transition, Panel Discussion). Sementara upaya-upaya yang harus dilakukan untuk menjawab tantangan di era revolusi industri 4.0, antara lain: 1. mengidentifikasi area strategis dalam rangka meningkatkan kecepatan, fleksibilitas, produktivitas, dan kualitas output. 2. menganalisa dampak pemanfaatan teknologi dalam jangka panjang, terutama terhadap serapan tenaga kerja dan lingkugan hidup. 3. mempersiapkan infrastruktur, serta program pendidikan dan keterampilan, sehingga mampu meningkatkan kapasitas sumberdaya manusia dalam penguasaan teknologi.

Santri di Pondok Pesantren Modern Muhammadiyah Boarding School Sleman Yogyakarta sudah menguasai teknologi dalam potensi penguasaan digital literacy. Namun, masih jauh dari yang diharapkan karena terdapat pembatas an durasi waktu dalam menggunakan teknologi informasi. Untuk mengetahui potensi literasi digital para santri ada beberapa indikator yang harus dikuasai yaitu keterampilan (use skill) merupakan keahlian dalam aktivitas akses dan pengoperasian media. Use skill memiliki tiga kriteria, yaitu keahlian dalam penggunaan media secara standar (rendah), keahlian secara aktif dalam penggunaan media, dan keahlian yang tinggi menggunakan dan memanfaatkan media.

Indikator keterampilan atau use skill khususnya pada pemanfaatan komputer/laptop dan handphone serta akses internet terdiri dari kepemilikan komputer/laptop dan handphone; penggunaan komputer/ laptop dan handphone di tinjau dari memiliki akun media sosial, e-mail serta situs yang sering dikunjungi; download dan upload. 
Pemahaman kritis (critical understanding) Kategori Individual Competence yang kedua adalah Critical Understanding atau pemahaman kritis merupakan kecakapan dalam melakukan analisis dan evaluasi isi berita pada media secara luas dan lengkap. Kriteria pemahaman kritis ini meliputi: kecakapan untuk memahami isi dan fungsi media, mempunyai pengetahuan tentang media dan aturan atau regulasi media, dan perilaku pengguna media dalam memanfaatkan media. Kriteria pemahaman kritis meliputi potensi santri terhadap berita pada media massa atau internet; mampu membedakan kebenaran isi konten berita dalam situs yang diterima; kemampuan memahami fungsi sosial media; dan melakukan cek sumber berita informasi yang didapatkan.

Santri harus memiliki kemampuan untuk menganalisis dan mengevaluasi konten media khususnya yang berasal dari media digital walaupun belum secara komprehensif. Meskipun santri yang notabennya tinggal di asrama sudah mampu memahami konten dan fungsi media serta memanfaatkannya sebagai salah satu sumber informasi dalam kegiatan pembelajaran.

Kemampuan komunikatif (communicative abilities) yaitu kecakapan dalam mengkomunikasikan dan berpartisipasi melalui saluran media. Kemampuan komunikasi merupakan kecakapan dalam membangun hubungan sosial mau berpartisipasi dalam lingkungan melalui saluran media. Selain itu, kemampuan komunikasi juga meliputi kecakapan dalam menyusun konten/isi media. Adapun indikator communicative abilities terdiri dari update informasi di internet.

Kemampuan komunikasi di internet terbatas pada kegiatan update status di media sosial yang tidak ada kaitannya dengan proses pembelajaran, melakukan kritik media sosial diluar materi pembelajaran, dan update berita dari internet untuk kepentingan peningkatan informasi pada dirinya sendiri.

Potensi santri dalam transformasi digital literacy memasuki era revolusi industri 4.0 sangat perlu diberi pembekalan agar ketika sudah lulus dari pesantren tersebut tidak kalah jauh dan kalah saing dengan lulusan yang sudah canggih dalam menggunakan internet tanpa ada pembatasan pada waktu SMA sederajat. Karena, pada revolusi industry 4.0 tidak hanya kecerdasan emosional yang dituntut. Akan tetapi harus mampu dalam berliterasi khususnya digital literacy. 


\section{KESIMPULAN}

Berdasarkan hasil penelitian di lapangan dan kajian pustaka yang sesuai hasil analisis, maka dapat mengambil beberapa kesimpulan antara lain sebagai berikut:

1. Potensi dalam transformasi digital literacy memasuki era revolusi industri 4.0 perlu dibekali sejak dini dengan catatan harus lebih waspada agar tidak menyimpang dari kecanggihan teknologi.

2. Pemahan digital literacy perlu diterapkan kepada guru dan santri supaya tidak kalah saing dengan yang sudah mahir menguasai teknologi dalam hal digital literacy.

3. Pemangku kebijakan pesantren harus memfasilitas dengan memaksimalkan waktu seefisien mungkin dalam proses belajar mengajar maupun di luar proses belajar mengajar sebagai salah satu upaya penguatan digital literacy pada guru, staf dan santri.

\section{DAFTAR PUSTAKA}

Akbar, M. F., \& Anggaraeni, F. D. (2017). Teknologi Dalam Pendidikan : Literasi Digital Dan Self-Directed Learning Pada Mahasiswa Skripsi. 2(1), 28-38.

Al-Husaini, A. I. T. B. (2010). Terjemahan Kifayatul Akhyar ll, terj. Achmad Zaidun dan A. Ma'ruf Asrori. Surabaya: Bina Ilmu Offset.

Anggraeni, H. Fauziyah, Y dan Fahyuni, E., F. (2019). Penguatan blended learning berbasis literasi digital dalam menghadapi era revolusi industri 4.0. 9.

Arifin, M. (1987). Filsafat Pendidikan Islam. Jakarta: Bina Aksara.

Budhirianto, S. (2016). Model Pemberdayaan Relawan Tik Dalam Meningkatkan ELiterasi Masyarakat Di Kota Sukabumi. Jurnal Penelitian Pos Dan Informatika, 6(1), 19-36. https://doi.org/10.17933/jppi.

Darmayanti, T., Setiani M. Y., \& Oetojo, B. (2007). Pada pendidikan jarak jauh: konsep yang mengubah metode pembelajaran di perguruan tinggi di indonesia. Jurnal Pendidikan Terbuka Dan Jarak Jauh, 8(2), 99-113.

Dewantara, K. H. (2011). Bagian pertama: Pendidikan (Cetakan Ke). Yogyakarta: Majelis Luhur Persatuan Tamansiswa.

Karel, A. S. (1984). Beberapa Aspek Tentang Islam di Indonesia Abad ke-19. Jakarta: Bulan Bintang.

Kurnianingsih, I., \& Ismayati, N. (2017). Upaya Peningkatan Kemampuan Literasi 
Digital bagi Tenaga Perpustakaan Sekolah dan Guru di Wilayah Jakarta Pusat Melalui Pelatihan Literasi Informasi. 3(1), 61-76.

Maunah, B. (2009). Tradisi Intelektual Santri. Yogyakarta: Suksek Offset.

Mulkan, A. M., D. (1998). Religiusitas Iptek: Rekonstruksi Pendidikan dan Tradisi Pesantren. Yogyakarta: Pustaka Pelajar-IAIN Sunan Kalijaga.

Mulyasa, E. (2005). Menjadi Guru Profesional. Bandung: PT. Remaja Rosda Karya.

Nurcholis, M. (1997). Bilik-bilik Pesantren Sebuah Potret Perjalanan. Jakarta: Paramadina.

Osman, K., Hiong, L. C., Vebrianto, R., \& Omar, Z. (2020). ScienceDirect 21 st Century Biology: An Interdisciplinary Approach of Biology, Technology, Engineering and Mathematics Education. 102(Ifee 2012), 188-194. https://doi.org/10.1016/j.sbspro.2013.10.732

Setyaningsih, R., \& Prihantoro, E. (2012). Model Penguatan Literasi Digital Melalui Pemanfaatan E-Learning.

Stefany, S. Nurbani, dan B. (2017). Literasi Digital Dan Pembukaan Diri : Studi Korelasi Penggunaan Media Sosial Pada Pelajar Remaja di Kota Medan Magister Ilmu Komunikasi , Fakultas Ilmu Sosial Ilmu Politik, Universitas Sumatera Utara. Magister Ilmu Komunikasi, Fakultas Ilmu Sosial Ilmu . 2(1), 10-31.

Subhan, A. (2012). Lembaga Pendidikan Islam Indonesia Abad Ke-20: Pergumulan AntaraModernisasi Dan Identitas. Jakarta: Kencana.

Suwito. (2004). Filsafat Pendidikan Akhlak Ibn Miskawaih. Yogyakarta: Belukar.

Wahid, M. dkk. (1999). Pondok Pesantren Masa Depan Wacana Pemberdayaan dan Transformasi Pondok Pesantren. Bandung: Pustaka 1999.

Wheeler, A. (2013). Designing Brand Identity: An Essential Guide for the Whole Branding Team. Canada: John Wiley \& Sons, Inc, Hoboken, New Jersey. 